\title{
Genetic parameters and genetic trends of conformation and management traits in Dairy Gir cattle
}

[Parâmetros genéticos e tendências genéticas de características de conformação e manejo de bovinos Gir Leiteiro]

\author{
N.S. Carvalho ${ }^{1}$, D.S. Daltro ${ }^{*}$, J.D. Machado ${ }^{1}$, E.V. Camargo ${ }^{2}$, \\ J.C.C. Panetto ${ }^{3}$, J.A. Cobuci ${ }^{1}$
}

\author{
${ }^{1}$ Universidade Federal do Rio Grande do Sul - Porto Alegre, RS \\ ${ }^{2}$ Instituto Federal de Educação - Ciência e Tecnologia Farroupilha - Alegrete, RS \\ ${ }^{3}$ Embrapa Gado de Leite - Juiz de Fora, MG
}

\begin{abstract}
The objective of this study was to estimate genetic parameters and genetic trends of different conformation and management traits regularly measured within the context of the National Dairy Gir Breeding Program (PNMGL). The estimation of genetic and residual variances for each trait was performed using average information restricted maximum likelihood (AI-REML) procedure in AIREMLF90 program software. The population was divided into three subpopulations constituted by measured females (with phenotype records), all females, and males. Linear regressions were applied for each trait, considering two periods of birth ( $1^{\text {st }}$ period: $1938-1996 ; 2^{\text {nd }}$ period: 1997-2012). The estimated heritability of conformation and management traits varied from 0.01 to 0.53 , denoting a perspective of genetic improvement through selection and corrective matings for purebred Dairy Gir populations. The average genetic changes in conformation and management traits were, in general, variable and inexpressive, showing that the selection of Dairy Gir may have had been directed essentially to increase milk yield. The analysis of the two periods of birth indicated that some linear traits present progress (although inexpressive) in the $2^{\text {nd }}$ period (more recent period).
\end{abstract}

Keywords: Zebu, Bos taurus indicus, genetic improvement, genetic progress, progeny test

\section{RESUMO}

O objetivo deste estudo foi estimar os parâmetros genéticos e as tendências genéticas para diferentes características de conformação e manejo de animais puros da raça Gir Leiteiro, pertencentes ao Programa Nacional de Melhoramento do Gir Leiteiro (PNMGL). A estimativa das variâncias genéticas e residuais para cada característica foi realizada usando-se o procedimento de máxima verossimilhança restrita (AI-REML), por meio do programa AIREMLF90. A população foi dividida em três subpopulações, constituídas por fêmeas mensuradas (com registros de fenótipo), todas fêmeas e machos. As regressões lineares para cada característica foram ainda divididas em dois períodos de anos de nascimento (1 ${ }^{\circ}$ período: 1938 a 1996; $2^{\circ}$ período: 1997 a 2012). As herdabilidades estimadas variaram de 0,01 a 0,53 para as características de conformação e manejo, possibilitando a perspectiva de melhoramento mediante seleção e acasalamentos corretivos na população pura da raça Gir Leiteiro. As mudanças genéticas nas características conformação e manejo foram, em geral, variáveis $e$ inexpressivas, sugerindo que a seleção no Gir Leiteiro possa ter sido direcionada essencialmente para maior produção de leite. Ao serem observados os dois períodos distintos de anos de nascimento, infere-se que algumas características lineares apresentaram progresso (embora inexpressivo) no $2^{\circ}$ período analisado.

Palavras-chave: Zebu, Bos taurus, melhoramento genético, progresso genético, teste de progênie

Recebido em 1 de maio de 2021

Aceito em 18 de maio de 2021

*Autor para correspondência (corresponding author)

E-mail:darlenedaltro@gmail.com 


\section{INTRODUCTION}

The use of zebu breeds and their crosses have been increasingly preferred for milk yield in tropical environments, where animals are frequently challenged. According to Canda (2014), zebu animals have progressively stood out in the Brazilian milk yield due to the great territorial area and climatic adversities. The growing concern about global warming and its effects in animal production may contribute to the increase of the use of zebu breeds, especially in crosses (Santana Júnior et al., 2015). Dairy Gir is one of the most used breeds by producers in Brazil to produce crossed milk cows (F1) (Wenceslau et al., 2000). This breed has a great importance for exports of semen, embryos, and animals from Brazil to several countries (Santos, 2013).

As the demand for pedigree animals grew, there was a need to implement a program to analyze bulls and matrices of the crossings that were already being carried out. Thus, in 1985, the Programa Nacional de Melhoramento do Gir Leiteiro (PNMGL) was created to favor the genetic improvement of Gir cattle and the selection of superior genetic traits for greater milk production, conformation, and management (Verneque, 2000). Reports by Tetzner (2016) corroborate the characteristics evaluated by the PNMGL; however, the author emphasizes that the selection intensity has traditionally been directed towards milk production. However, the same author reported that, as the traits related to milk production evolved, other functional traits, linked to conformation and management, started requiring special attention by the breeding program.

According to Tetzner (2016), for an animal to have its production optimized, not only for lactation, but mainly throughout its useful life, it is essential that it presents morphological structure and body condition capable of maintaining production and permanence in the herd. Thus, the type or conformation traits can influence the production and management of animals, as they have a direct or indirect relationship with these aspects (McManus \& Saueressig, 1998).

The "functional type", a term suggested to refer to the body's conformation associated with milk production during the productive life of a cow, has been investigated in several studies (Campos et al., 2012; Lagrotta et al., 2010; Pereira et al., 2010). Most studies have concluded that the type and production traits, seem to be independently inherited, and to improve them, it is necessary that selection is practiced in both (Campos et al., 2012).

According to Canda (2014), the effectiveness of a breeding program should be evaluated by means of estimation of genetic trends. The study of genetic trends is a way of measuring accumulated changes in a population and is an indicator of the reached genetic progress (Missanjo et al., 2012). Moreover, estimates of genetic trends are required to monitor and evaluate breeding programs (Abdallah \& McDaniel, 2000) and to assist in decision making during the genetic improvement process.

However, updated estimates of genetic parameters in the dairy Gir breed and studies of genetic trends in conformation and management traits in dairy Zebu breeds are scarce in the literature. In view of the exposed scenario and the prospect of expanding the Brazilian Dairy Gir genetics to the world, it is essential to obtain and analyze genetic trends, aiming to evaluate the genetic progress achieved in pure animals and, thus, to identify which characteristics require more attention in the coming years in this subpopulation. Thus, the objective of this study was to estimate genetic parameters and genetic trends of conformation and management traits of dairy Gir animals.

\section{MATERIAL AND METHODS}

The data used were from the PNMGL, provided by the Brazilian Agricultural Research Corporation (EMBRAPA). They consisted of 9.394 linear evaluations of conformation and management traits (Table 1). The data of some animals were excluded for a better consistency and higher quality of overall data; these data were from cows born before 1999 or after 2012, cows evaluated before 2005 and after 2015, and cows with ages below 29 or above 64 months at the time of evaluation. The data of all cows with unknown parents, incomplete evaluations, or duplicated evaluations were also excluded. 
In addition to the phenotypic records, Embrapa Gado de Leite provided a set of genealogical data (pedigree) of the population. Considering all possible generations, new pedigree bases were generated, aiming at the formation of kinship matrices, combined with animals with phenotype records for linear traits (conformation and management), resulting in a total of 7,123 individuals (Table 1). This genealogical database was used in all subsequent analyzes to predict the genetic values of the animals.

The population structure of the genealogical database, whose information was obtained through the CFC software (Sargolzaei et al., 2006), had 13 generations for the linear traits. The total number of parents reached 1,223 (linear), with the total progeny of the parents equal to 5,826 (linear). The average family size was 2.44 for linear traits.

Table 1. Data structure in the analyzed file of conformation and management traits in Dairy Gir cattle.

\begin{tabular}{lc}
\hline Data base & \\
\hline $\begin{array}{l}\text { Total number of animals with } \\
\text { phenotype }\end{array}$ & 9.394 \\
Cow age (months) & 29 a 64 \\
Number of animals in pedigree file & 7.123 \\
Number of mothers in pedigree file & 4.119 \\
Number of fathers in pedigree file & 1.223 \\
Number of progeny pedigree file & 5.708 \\
Number contemporaneous group & 934 \\
Number of evaluators & 45 \\
\hline
\end{tabular}

Contemporary groups were formed by criteria of herd and year of calving and constituted by at least three daughters of at least two different sires. In the analyses, the effects of the contemporary group, evaluation season (rainy season $=$ October to March; dry season $=$ April to September), evaluator were considered fixed; and cow age at calving (months) was considered a covariable (linear and quadratic effect); the additive genetic random effect of the animal and the residual effect were considered random effects. The following model was used for all conformation and management linear traits:

$$
\mathrm{y}=\mathrm{X} \beta+\mathrm{Zu}+\mathrm{e},
$$

were $y$ is the vector of evaluations for the linear traits; $\beta$ is the vector of fix effects previously defined; $u \sim \mathrm{N}\left(0, A \sigma^{2} a\right)$ is the vector of additive genetic random effect of animal; $e \sim \mathrm{N}\left(0\right.$, I $\left.n \sigma^{2} e\right)$ is the vector of residual random effect; and $X$ and $Z$ are matrices of incidence associated with fixed and random effects of the animal, respectively. The genetic parameters were estimated and the genetic values were predicted by single trait animal model analysis, through the programs of the BLUPF90 families (Misztal et al., 2002), using the AIREMLF90 software and assuming the convergence criterion of $10^{-12}$. The genetic trends were estimated for three subpopulations formed by measured females (females with phenotype trait records), females (all, including mothers and grandmothers without phenotype) and males. All traits were evaluated by linear regression with mean genetic values as a function of year of birth of the animals. Considering the year of birth of the animals, the whole evaluated period was 1938 to 2012 . Considering that the publishing of genetic evaluations for these traits begun in 1997, two additional periods of birth were analyzed: 1938$1996\left(1^{\text {st }}\right.$ period $)$ and 1997-2012 ( $2^{\text {nd }}$ period $)$ for the general female subpopulation; and 1942$1996\left(1^{\text {st }}\right.$ period $)$ and $1997-2009$ ( $2^{\text {nd }}$ period $)$ for the male subpopulation. Additional periods were not used for measured female subpopulation because all these animals were born after 1997 and were included in the general female subpopulation.

\section{RESULTS AND DISCUSSION}

The results showed that $50 \%$ of the conformation and management traits presented heritability estimates higher than 0.15 (Table 2), and 77\% higher than 0.10, indicating that part of the variation is due to the additive effect of genes, as described by Lagrotta et al. (2010). Although they are estimates of moderate to low magnitude, it allows for the prospect that genetic gains can be achieved through selection. Everling et al. (2012), report that low values of heritability suggest that the characteristics should respond slowly to the selection. Thus, we can infer that if the national breeder starts to focus on the selection of their breeding animals based on predicted transmitting ability (PTA), instead of using almost strictly the phenotypic performance as a choice criterion, more significant genetic gain will occur, thus generating a positive perspective for the improvement of the local herd. 
For McManus and Saueressig (1998), the selection also for type traits aims to increase the productive life of the cows. The term "lineartype traits" is used to refer to those characteristics that improve the efficiency of the cow not by increasing its productivity, but by reducing its production costs (Groen et al., 1997). For Tetzner (2016), the "type" or "exterior of the animal" refers to the general appearance related to the productive function. In this sense, two reasons for selecting conformation can be cited: meeting the market demand for a certain animal type and obtaining, in part, indirect response to productivity, functionality, and longevity.

The heritability of conformation and management traits, in general, varied from 0.01 to 0.53 in the present study (Table 2). Good results were found for navel length, which is an important morphological attribute for evaluation of zebu herds, presenting the highest estimates (0.53) and similar values to that reported for Dairy Gir cattle by Panetto et al. (2017) (0.46) in a genetic evaluation using a population similar that evaluated in the present work. Bignardi et al. (2011) found that the heritability estimates for navel score at different ages in cattle suggested that this trait should respond to individual selection with possible genetic gain. It is known that animals with larger navels or with poor positioning are more susceptible to pathologies, impairing the functionality of the breeders (Koury Filho et al., 2003). Thus, the evaluation of the size and position of the navel is of great importance in the selection of breeders, in the sense of enabling the improvement of the trait by choosing bulls with a desirable navel (Boligon et al., 2016).

Table 2. Genetic parameters of a purebred population of the PNMGL evaluated in the present study

\begin{tabular}{lcccc}
\multicolumn{1}{c}{ Trait } & $\mathrm{h}^{2}$ & $\sigma^{2} \mathrm{a}$ & $\sigma^{2} \mathrm{e}$ & $\sigma^{2}$ total \\
\hline Rump height & $0.31( \pm 0.09)$ & 4.934 & 10.871 & 10875.934 \\
Thoracic perimeter & $0.23( \pm 0.07)$ & 9.529 & 32.026 & 41.555 \\
Body length & $0.11( \pm 0.06)$ & 1.660 & 12.737 & 14.397 \\
Rump length & $0.16( \pm 0.06)$ & 0.725 & 3.721 & 4.446 \\
Width between ischia & $0.21( \pm 0.07)$ & 0.510 & 1.953 & 2.463 \\
Width between ilia & $0.13( \pm 0.06)$ & 0.771 & 5.003 & 5.774 \\
Rump angle & $0.07( \pm 0.04)$ & 1.814 & 21.988 & 23.802 \\
Hoof wall angle & $0.14( \pm 0.06)$ & 0.144 & 0.899 & 1.043 \\
Leg position (lateral view) & $0.14( \pm 0.06)$ & 0.141 & 0.881 & 1.022 \\
Leg position (back view) & $0.01( \pm 0.03)$ & 0.010 & 0.636 & 0.646 \\
Fore udder attachment & $0.06( \pm 0.04)$ & 0.133 & 2.143 & 2.276 \\
Rear udder width & $0.20( \pm 0.08)$ & 0.275 & 1.122 & 1.397 \\
Udder depth & $0.29( \pm 0.08)$ & 0.533 & 1.306 & 1.839 \\
Teat length & $0.44( \pm 0.09)$ & 0.762 & 0.959 & 1.721 \\
Teat diameter & $0.19( \pm 0.07)$ & 0.076 & 0.325 & 0.401 \\
Temper & $0.13( \pm 0.06)$ & 0.344 & 2.214 & 2.558 \\
Navel length & $0.53( \pm 0.09)$ & 3.320 & 2.962 & 6.282 \\
\hline
\end{tabular}

The five rump-related traits evaluated (rump height, rump angle, rump length, width between ilia, and width between ischia) presented low to moderate heritability, varying from 0.07 to 0.31 . Considering correspondent classifications to maximum two lactations, Lagrotta et al. (2010) found variation of 0.26 to 0.54 for these traits in Dairy Gir cattle. A sufficiently high rump is desirable to maintain the udder distant from the soil (Panetto et al., 2017), thus, the variation found in the present study for rump height $(0.31)$ (Table 2) denotes the possibility of selection and improvement of this attribute. These results agree with Lagrotta et al. (2010), in which the morphological trait croup height showed great potential for response to selection in breeding programs of the dairy Gir breed. Pereira et al. (2010) stated that the croup height trait is easy to measure and less susceptible to variations of the environment.

The five mammary system traits (teat length, teat diameter, rear udder width, fore udder attachment, and udder depth) showed a large variation of heritability estimates (0.06 to 0.44 ), which is an indication that the udder depth 
(0.29), rear udder width (0.20), and teat diameter (0.19) can present good responses to selection. Similar variations were found by Panetto et al. (2017) for the same traits in purebred Dairy Gir cows (0.07 to 0.40$)$. Teat length should be emphasized here to the heritability found $(0.44)$; it was in accordance with Lagrotta et al. (2010), who found the same estimate for this trait, and was similar to those found by Wenceslau et al. (2000) (0.46) and Panetto et al. (2017) (0.40), all for Dairy Gir cows. Considering that too long or too short teats hinder the milking and colostrum sucking by the calf and are related to increased mastitis and loss of teats (Panetto et al., 2017), the heritability found shows the viability of selection for this trait.

The measurement of linear-type traits is gaining importance because they are genetically related to the longevity of cows, besides assisting producers in the selection of animals for production (Campos et al., 2012). This same author stated that some works have shown that the selection only for milk production can cause negative effects on some traits of udder conformation, which reinforces the need for attention to these traits, justifying the importance of linear evaluations for the improvement of the mammary system, for example. Tetzner (2016) pointed out that type traits deserve attention when the objective is to maximize the productive life of the animal, avoiding early discards due to udder ligament problems and also for conformation, for example.

The heritability found (Table 2) for the two bodily structure traits evaluated (body length and thoracic perimeter) were the same as those estimated by Wenceslau et al. (2000), who reported heritability of 0.11 (body length) and 0.23 (thoracic perimeter) for Dairy Gir cattle. Little higher values ( 0.18 and 0.30 , respectively) were found by Lagrotta et al. (2010) for Dairy Gir cattle.

The selection for traits related to legs and feet are associated with the animals' locomotion ability, which is essential to allow good mobility and longevity. The three traits related to legs and feet (hoof wall angle, leg position - back view, and leg position - lateral view) presented low to slightly moderate heritability, ranging from 0.01 to 0.14 (Table 2). Similar results were found by Bohlouli et al. (2015) from data of seven
Holstein cattle herds in Iran, which presented heritability of 0.06 to 0.15 in a multicharacteristic analysis. Lagrotta et al. (2010) evaluated purebred Dairy Gir cattle and found heritability of 0.09 for hoof wall angle, and 0.14 for leg position - lateral view. The low heritability found for leg position - back view (0.01) is in accordance with the results of Panetto et al. (2017) for purebred Dairy Gir animals, which presented the same value.

The residual variance $\left(\sigma^{2} \mathrm{e}\right)$ for this trait was significantly higher to the additive genetic variance $\left(\sigma^{2} a\right)$ (Table 2$)$, denoting considerable environmental effect on its variation and expression. Thus, obtaining considerable genetic gain for these traits becomes a major challenge in dairy farming, considering its great impact on the profitability of properties and on the health and welfare of dairy cows, forming an important group of traits in selection programs of dairy cattle.

The heritability estimates found for rump angle (0.07), fore udder attachment (0.06), and leg position - back view (0.01) were low, according to Pereira (2012), and indicate little effect of genetic factors on the population evaluated in the present study. Thus, little response to selection can be expected for these traits. However, as any other trait, heritability estimates for conformation attributes may vary significantly according to the breed, classification system, statistical model used, number of records by animal, and data edition procedures (Bohlouli et al., 2015). The results for the management traits showed that the temper, which is important to describe the animal docility, had a similar heritability $(0.13)$ to that found by Panetto et al. (2017) (0.12) in the Dairy Gir sire summary of the PNMGL. Although it is a low estimate, genetic gains can be reached also by means of selection, but probably, at a slower rate.

The linear traits (conformation and management) presented, in general, high variability over time (Tables 3, 4, and 5). Considering specifically the conformation traits, annual percentage changes in the whole period varied from -0.04 to $0.22 \%$ for measured females, -0.03 to $0.09 \%$ for females, and -0.02 to $0.05 \%$ for males. In the $1^{\text {st }}$ period, the variation of these percentage changes was -0.01 to $0.04 \%$ for females, and -0.01 to $0.03 \%$ for males; and in the $2^{\text {nd }}$ period, it was - 
0.10 to $0.34 \%$ for females, and -0.30 to $0.29 \%$ for males. Despite the most annual means of genetic values were not significantly different than zero, part of the linear traits showed progresses, although little.

In the whole period, the highest coefficients of regression for the subpopulation of measured females (Table 3) were found for rump height, body length, and rump length traits; and for the females (Table 4) and males (Table 5), the highest coefficients were found for the rump height, body length, and navel length traits. The body length trait presented the second highest coefficients of regression for the two subpopulations of females, and the highest coefficient to the subpopulation of males.

The annual genetic trends for the conformation and management traits in the whole period varied from -0.013 to 0.041 . These values are within the range reported by Kruszyński et al. (2013) for Holstein cattle in Poland; they found low annual genetic changes (coefficients of regression) for 18 conformation and management traits individually evaluated, with values from -0.045 to 0.052 . In the $2^{\text {nd }}$ period, the coefficients of regression found in the present work presented large variation, from -0.080 for thoracic perimeter in males to 0.048 for rump height in females.

The annual percentage gains for the five rump traits were positive in the whole evaluated period, varying from 0.00 to $0.04 \%$ in all populations (Tables 3, 4, and 5). Regarding the legs and feet, changes with high amplitude were found for all animals, varying from -0.01 to $0.06 \%$ over time for the three evaluated traits. However, the hoof wall angle trait presented higher annual percentage gain for males $(0.04 \%)$ than any other conformation trait evaluated. The bodily structure traits had lower increases, varying from 0.00 to $0.02 \%$ for all females (including the measured ones) and males.

Table 3. Coefficients of regression for the PNMGL population: measured females

\begin{tabular}{|c|c|c|c|c|c|}
\hline Trait & Period & b & $\%$ & $\pm \mathrm{SE}$ & $\mathrm{R}^{2}$ \\
\hline Rump height & Whole period & 0.04104 & 0.03 & 0.00689 & 0.019 \\
\hline Rump angle & Whole period & 0.00877 & 0.04 & 0.00361 & 0.003 \\
\hline Hoof wall angle & Whole period & 0.00273 & 0.06 & 0.00108 & 0.003 \\
\hline Body length & Whole period & 0.01946 & 0.02 & 0.00310 & 0.021 \\
\hline Rump length & Whole period & 0.01754 & 0.04 & 0.00251 & 0.026 \\
\hline Teat length & Whole period & 0.00060 & 0.01 & 0.00319 & 0.000 \\
\hline Teat diameter & Whole period & 0.00268 & 0.07 & 0.00079 & 0.006 \\
\hline Rear udder width & Whole period & 0.01148 & 0.20 & 0.00134 & 0.038 \\
\hline Width between ilia & Whole period & 0.01434 & 0.03 & 0.00259 & 0.016 \\
\hline Width between ischia & Whole period & 0.00044 & 0.00 & 0.00187 & 0.000 \\
\hline Fore udder attachment & Whole period & -0.00254 & -0.04 & 0.00077 & 0.006 \\
\hline Thoracic perimeter & Whole period & 0.01413 & 0.01 & 0.00945 & 0.0012 \\
\hline Leg position (lateral view) & Whole period & 0.00093 & 0.02 & 0.00098 & 0.000 \\
\hline Leg position (back view) & Whole period & -0.00041 & -0.01 & 0.00012 & 0.006 \\
\hline Udder depth & Whole period & 0.01046 & 0.22 & 0.00229 & 0.011 \\
\hline Navel length & Whole period & 0.00898 & 0.09 & 0.00680 & 0.001 \\
\hline Temper & Whole period & -0.01303 & -0.36 & 0.00141 & 0.044 \\
\hline
\end{tabular}

$\mathrm{b}=$ coefficient of regression; $\pm \mathrm{SE}=$ standard error; $\mathrm{R}^{2}=$ coefficient of determination. Whole period = 1999 to 2012. 
Table 4. Coefficients of regression for the PNMGL population: females

\begin{tabular}{|c|c|c|c|c|c|}
\hline Trait & Period & $\mathrm{b}$ & $\%$ & $\pm \mathrm{SE}$ & $\mathrm{R}^{2}$ \\
\hline \multirow{3}{*}{ Rump height } & $1^{\text {st }}$ period & -0.00259 & -0.00 & 0.00074 & 0.004 \\
\hline & $2^{\text {nd }}$ period & 0.04833 & 0.03 & 0.00453 & 0.037 \\
\hline & Whole period & 0.01211 & 0.01 & 0.00064 & 0.056 \\
\hline \multirow{3}{*}{ Rump angle } & $1^{\text {st }}$ period & -0.00102 & -0.00 & 0.00026 & 0.005 \\
\hline & $2^{\text {nd }}$ period & 0.01224 & 0.05 & 0.00234 & 0.009 \\
\hline & Whole period & 0.00235 & 0.01 & 0.00031 & 0.009 \\
\hline \multirow{3}{*}{ Hoof wall angle } & $1^{\text {st }}$ period & 0.00055 & 0.01 & 0.00009 & 0.011 \\
\hline & $2^{\text {nd }}$ period & 0.00295 & 0.06 & 0.00074 & 0.005 \\
\hline & Whole period & 0.00167 & 0.03 & 0.00001 & 0.045 \\
\hline \multirow{3}{*}{ Body length } & $1^{\text {st }}$ period & 0.00250 & 0.00 & 0.00029 & 0.024 \\
\hline & $2^{\text {nd }}$ period & 0.01750 & 0.01 & 0.00208 & 0.023 \\
\hline & Whole period & 0.00632 & 0.00 & 0.00028 & 0.077 \\
\hline \multirow{3}{*}{ Rump length } & $1^{\text {st }}$ period & 0.00080 & 0.00 & 0.00023 & 0.004 \\
\hline & $2^{\text {nd }}$ period & 0.02050 & 0.04 & 0.00163 & 0.050 \\
\hline & Whole period & 0.00499 & 0.01 & 0.00022 & 0.076 \\
\hline \multirow{3}{*}{ Teat length } & $1^{\text {st }}$ period & -0.00097 & -0.01 & 0.00032 & 0.003 \\
\hline & $2^{\text {nd }}$ period & 0.00003 & 0.00 & 0.00214 & 0.000 \\
\hline & Whole period & -0.00021 & 0.00 & 0.00029 & 0.000 \\
\hline \multirow{3}{*}{ Teat diameter } & $1^{\text {st }}$ period & -0.00058 & -0.01 & 0.00007 & 0.020 \\
\hline & $2^{\text {nd }}$ period & 0.00172 & 0.04 & 0.00053 & 0.003 \\
\hline & Whole period & -0.00007 & 0.00 & 0.00007 & 0.000 \\
\hline \multirow{3}{*}{ Rear udder width } & $1^{\text {st }}$ period & 0.00069 & 0.01 & 0.00015 & 0.007 \\
\hline & $2^{\text {nd }}$ period & 0.01601 & 0.28 & 0.00087 & 0.101 \\
\hline & Whole period & 0.00433 & 0.07 & 0.00013 & 0.159 \\
\hline \multirow{3}{*}{ Width between ilia } & $1^{\text {st }}$ period & 0.00021 & 0.00 & 0.00019 & 0.000 \\
\hline & $2^{\text {nd }}$ period & 0.01870 & 0.04 & 0.00165 & 0.041 \\
\hline & Whole period & 0.00233 & 0.00 & 0.00022 & 0.022 \\
\hline \multirow{3}{*}{ Width between ischia } & $1^{\text {st }}$ period & 0.00247 & 0.01 & 0.00021 & 0.046 \\
\hline & $2^{\text {nd }}$ period & -0.00096 & -0.00 & 0.00126 & 0.000 \\
\hline & Whole period & 0.00328 & 0.02 & 0.00017 & 0.055 \\
\hline \multirow{3}{*}{ Fore udder attachment } & $1^{\text {st }}$ period & -0.00001 & -0.00 & 0.00007 & 0.000 \\
\hline & $2^{\text {nd }}$ period & -0.00579 & -0.10 & 0.00053 & 0.038 \\
\hline & Whole period & -0.00189 & 0.03 & 0.00007 & 0.099 \\
\hline \multirow{3}{*}{ Thoracic perimeter } & $1^{\text {st }}$ period & 0.00233 & 0.00 & 0.00083 & 0.003 \\
\hline & $2^{\text {nd }}$ period & -0.00019 & -0.00 & 0.00626 & 0.000 \\
\hline & Whole period & 0.00391 & 0.00 & 0.00084 & 0.003 \\
\hline \multirow{3}{*}{ Leg position (lateral view) } & $1^{\text {st }}$ period & -0.00014 & -0.00 & 0.00010 & 0.001 \\
\hline & $2^{\text {nd }}$ period & 0.00167 & 0.03 & 0.00066 & 0.002 \\
\hline & Whole period & -0.00025 & 0.00 & 0.00009 & 0.001 \\
\hline \multirow{3}{*}{ Leg position (back view) } & $1^{\text {st }}$ period & -0.00010 & -0.00 & 0.00001 & 0.023 \\
\hline & $2^{\text {nd }}$ period & -0.00013 & -0.00 & 0.00008 & 0.001 \\
\hline & Whole period & -0.00001 & 0.00 & 0.00001 & 0.012 \\
\hline \multirow{3}{*}{ Udder depth } & $1^{\text {st }}$ period & 0.00183 & 0.04 & 0.00024 & 0.019 \\
\hline & $2^{\text {nd }}$ period & 0.01590 & 0.34 & 0.00153 & 0.035 \\
\hline & Whole period & 0.00356 & 0.07 & 0.00021 & 0.044 \\
\hline \multirow{3}{*}{ Navel length } & $1^{\text {st }}$ period & 0.00115 & 0.01 & 0.00063 & 0.001 \\
\hline & $2^{\text {nd }}$ period & 0.02271 & 0.22 & 0.00438 & 0.008 \\
\hline & Whole period & 0.00937 & 0.09 & 0.00060 & 0.039 \\
\hline \multirow{3}{*}{ Temper } & $1^{\text {st }}$ period & -0.00060 & -0.01 & 0.00016 & 0.004 \\
\hline & $2^{\text {nd }}$ period & -0.01272 & -0.35 & 0.00097 & 0.055 \\
\hline & Whole period & -0.00295 & -0.08 & 0.00014 & 0.071 \\
\hline
\end{tabular}

$\mathrm{b}=$ coefficient of regression; $\pm \mathrm{SE}=$ standard error; $\mathrm{R}^{2}=$ coefficient of determination.

$1^{\text {st }}$ period $=1938$ to $1996,2^{\text {nd }}$ period $=1997$ to 2012 , whole period $=1938$ to 2012 . 
Table 5. Coefficients of regression of population of PNMGL: Males

\begin{tabular}{|c|c|c|c|c|c|}
\hline Trait & Period & $\mathrm{b}$ & $\%$ & $\pm \mathrm{SE}$ & $\mathrm{R}^{2}$ \\
\hline \multirow{3}{*}{ Rump height } & $1^{\text {st }}$ period & -0.00191 & -0.00 & 0.00131 & 0.002 \\
\hline & $2^{\text {nd }}$ period & 0.00103 & 0.00 & 0.03588 & 0.000 \\
\hline & Whole period & 0.00514 & 0.00 & 0.00126 & 0.013 \\
\hline \multirow{3}{*}{ Rump angle } & $1^{\text {st }}$ period & -0.00084 & -0.00 & 0.00047 & 0.003 \\
\hline & $2^{\text {nd }}$ period & -0.03083 & -0.14 & 0.01824 & 0.022 \\
\hline & Whole period & 0.00014 & 0.00 & 0.00051 & 0.000 \\
\hline \multirow{3}{*}{ Hoof wall angle } & $1^{\text {st }}$ period & 0.00053 & 0.01 & 0.00016 & 0.010 \\
\hline & $2^{\text {nd }}$ period & 0.00960 & 0.20 & 0.00664 & 0.016 \\
\hline & Whole period & 0.00181 & 0.04 & 0.00019 & 0.070 \\
\hline \multirow{3}{*}{ Body length } & $1^{\text {st }}$ period & 0.00207 & 0.00 & 0.00048 & 0.016 \\
\hline & $2^{\text {nd }}$ period & 0.04377 & 0.04 & 0.02040 & 0.035 \\
\hline & Whole period & 0.00572 & 0.00 & 0.00057 & 0.076 \\
\hline \multirow{3}{*}{ Rump length } & $1^{\text {st }}$ period & 0.00060 & 0.00 & 0.00042 & 0.002 \\
\hline & $2^{\text {nd }}$ period & 0.02650 & 0.06 & 0.01374 & 0.028 \\
\hline & Whole period & 0.00214 & 0.00 & 0.00043 & 0.020 \\
\hline \multirow{3}{*}{ Teat length } & $1^{\text {st }}$ period & -0.00155 & 0.02 & 0.00053 & 0.007 \\
\hline & $2^{\text {nd }}$ period & 0.00514 & 0.07 & 0.01749 & 0.001 \\
\hline & Whole period & -0.00144 & -0.02 & 0.00054 & 0.006 \\
\hline \multirow{3}{*}{ Teat diameter } & $1^{\text {st }}$ period & -0.00059 & -0.01 & 0.00013 & 0.018 \\
\hline & $2^{\text {nd }}$ period & 0.00663 & 0.18 & 0.00421 & 0.019 \\
\hline & Whole period & -0.00047 & -0.01 & 0.00013 & 0.010 \\
\hline \multirow{3}{*}{ Rear udder width } & $1^{\text {st }}$ period & 0.00061 & 0.01 & 0.00024 & 0.005 \\
\hline & $2^{\text {nd }}$ period & 0.01690 & 0.29 & 0.00674 & 0.047 \\
\hline & Whole period & 0.00182 & 0.03 & 0.00024 & 0.043 \\
\hline \multirow{3}{*}{ Width between ilia } & $1^{\text {st }}$ period & 0.00038 & 0.00 & 0.00036 & 0.001 \\
\hline & $2^{\text {nd }}$ period & 0.00847 & 0.01 & 0.01178 & 0.004 \\
\hline & Whole period & 0.00027 & 0.00 & 0.00036 & 0.000 \\
\hline \multirow{3}{*}{ Width between ischia } & $1^{\text {st }}$ period & 0.00175 & 0.01 & 0.00037 & 0.020 \\
\hline & $2^{\text {nd }}$ period & 0.00080 & 0.00 & 0.01005 & 0.000 \\
\hline & Whole period & 0.00265 & 0.01 & 0.00035 & 0.045 \\
\hline \multirow{3}{*}{ Fore udder attachment } & $1^{\text {st }}$ period & -0.00013 & -0.00 & 0.00013 & 0.001 \\
\hline & $2^{\text {nd }}$ period & 0.00457 & 0.08 & 0.00453 & 0.008 \\
\hline & Whole period & -0.00043 & -0.01 & 0.00013 & 0.008 \\
\hline \multirow{3}{*}{ Thoracic perimeter } & $1^{\text {st }}$ period & 0.00089 & 0.00 & 0.00149 & 0.000 \\
\hline & $2^{\text {nd }}$ period & -0.08025 & -0.04 & 0.04219 & 0.028 \\
\hline & Whole period & 0.00397 & 0.00 & 0.00143 & 0.048 \\
\hline \multirow{3}{*}{ Leg position (lateral view) } & $1^{\text {st }}$ period & -0.00030 & -0.00 & 0.00018 & 0.002 \\
\hline & $2^{\text {nd }}$ period & 0.00105 & 0.02 & 0.00624 & 0.000 \\
\hline & Whole period & -0.00067 & -0.01 & 0.00018 & 0.011 \\
\hline \multirow{3}{*}{ Leg position (back view) } & $1^{\text {st }}$ period & -0.00007 & -0.00 & 0.00002 & 0.010 \\
\hline & $2^{\text {nd }}$ period & -0.00107 & -0.02 & 0.00060 & 0.024 \\
\hline & Whole period & -0.00011 & 0.00 & 0.00002 & 0.023 \\
\hline \multirow{3}{*}{ Udder depth } & $1^{\text {st }}$ period & 0.00167 & 0.03 & 0.00042 & 0.014 \\
\hline & $2^{\text {nd }}$ period & 0.00323 & 0.07 & 0.01275 & 0.000 \\
\hline & Whole period & 0.00076 & 0.01 & 0.00041 & 0.003 \\
\hline \multirow{3}{*}{ Navel length } & $1^{\text {st }}$ period & 0.00070 & 0.00 & 0.00110 & 0.000 \\
\hline & $2^{\text {nd }}$ period & -0.03090 & -0.30 & 0.02849 & 0.009 \\
\hline & Whole period & 0.00502 & 0.05 & 0.00104 & 0.019 \\
\hline \multirow{3}{*}{ Temper } & $1^{\text {st }}$ period & -0.00061 & -0.01 & 0.00029 & 0.004 \\
\hline & $2^{\text {nd }}$ period & -0.02381 & -0.66 & 0.00751 & 0.073 \\
\hline & Whole period & -0.00179 & -0.05 & 0.00027 & 0.033 \\
\hline
\end{tabular}

$\mathrm{b}=$ coefficient of regression; $\pm \mathrm{SE}=$ standard error; $\mathrm{R}^{2}=$ coefficient of determination. $1^{\text {st }}$ period $=1942$ to $1996,2^{\text {nd }}$ period $=1997$ to 2009 , whole period $=1942$ to 2009 . 
The mammary system traits showed the two highest annual percentage gains, all in the measured female group. The annual percentage gains for udder depth $(0.22 \%)$ and rear udder width $(0.20 \%)$ stood out among the evaluated conformation traits. These traits presented the highest annual percentage gains in the subpopulation of general females (both with $0.07 \%$ ). However, the variation of the annual percentage changes in this group of traits was $0.04 \%$ to $22 \%$. All other annual percentage changes found for conformation traits were lower than $0.09 \%$. The absence of expressive genetic improvement was observed when analyzing the coefficients of regression (Tables 3, 4, and 5) and, even more clearly, when analyzing the genetic annual percentage changes (0.05 to $0.09 \%$ ) for the navel length trait, for which low scores (near $1=$ short navel) are desirable (Panetto et al., 2017).

The phenotypic mean of this trait (Table 6) shows that the medium score of this population was slightly higher than 5 , equivalent to $9.8 \mathrm{~cm}$ (Panetto et al., 2017). These results are indicative an increase in navel size of males and females over the whole evaluated period. Similarly, the fore udder attachment presented low phenotypic mean, which is below the ideal score (9), and negative coefficients of regression for the three subpopulations evaluated (measured females, females, and males).

Table 6. Phenotypic means, standard deviations (SD), and ideal means for the evaluated traits ${ }^{4}$.

\begin{tabular}{|c|c|c|c|}
\hline Trait & Mean & SD & Ideal mean $^{(3)}$ \\
\hline Rump height (cm) & 136.68 & 4.89 & $>136$ \\
\hline Rump angle ${ }^{(2)}$ & 21.97 & 7.33 & 27.2 \\
\hline Hoof wall angle ${ }^{(1)}$ & 4.68 & 1.15 & 5 \\
\hline Body length $(\mathrm{cm})$ & 103.45 & 4.68 & $>102$ \\
\hline Rump length (cm) & 44.06 & 3.21 & $>40$ \\
\hline Navel length (cm) & 10.17 & 2.76 & 1 \\
\hline Teat length $(\mathrm{cm})$ & 6.70 & 1.51 & \pm 7.5 \\
\hline Teat diameter $(\mathrm{cm})$ & 3.71 & 1.00 & $<$ or $=3.8$ \\
\hline Ease of milking ${ }^{(1)}$ & 3.48 & 1.58 & 1 \\
\hline Rear udder width ${ }^{(1)}$ & 5.76 & 1.95 & 9 \\
\hline Width between ilia (cm) & 44.94 & 3.86 & $>48$ \\
\hline Width between ischia $(\mathrm{cm})$ & 18.55 & 2.49 & $>18$ \\
\hline Fore udder attachment ${ }^{(1)}$ & 5.69 & 1.92 & 9 \\
\hline Thoracic perimeter $(\mathrm{cm})$ & 175.87 & 7.96 & $>175$ \\
\hline Leg position (lateral view) ${ }^{(1)}$ & 5.15 & 1.14 & 5 \\
\hline Leg position (back view) ${ }^{(1)}$ & 4.79 & 0.89 & 5 \\
\hline Udder depth ${ }^{(1)}$ & 4.68 & 1.56 & 5 \\
\hline Temper $^{(1)}$ & 3.62 & 1.73 & 1 \\
\hline
\end{tabular}

1 trait measured in scores of 1 to 9 .

2 trait measured in degrees.

${ }^{3}$ According to the sire summaries of the PNMGL (Panetto et al., 2017).

${ }^{4}$ Subpopulation of measured females that born from 1999 to 2012.

These results denote that the predicted genetic values for the population did not favor the increase of mean scores for this trait over the whole period. Thus, annual percentage changes varied from -0.01 to $-0.04 \%$. Not desirable results were also found for teat diameter in the measured females. In this case, the positive coefficient of regression (Table 3) showed an annual genetic change of $0.07 \%$; however, the phenotypic mean found for this trait was within the ideal range, according to Panetto et al. (2017). Thus, there was a slight or inexpressive increase in the teat diameter in this subpopulation in the whole period. The temper showed negative annual genetic changes (Table 3,4 , and 5), indicating a genetic improvement in all periods evaluated; low scores are desirable for this trait - score 1 is attributed to very docile cattle and 9 to very fierce ones (Panetto et al., 2017). The percentage gains confirmed this result in the whole evaluated period for measured females $(-0.36 \%)$, females $(-0.08 \%)$, and males ($0.05 \%)$. Kruszyński et al. (2013) evaluate Holstein cattle in Poland and found absence of 
genetic improvement for temper (-0.045 points per year), however, in that country, high scores (near 9) indicate high docility. The gains found for conformation and management traits, were, in general, low and inexpressive in the whole evaluated period, indicating that the selection was directed to milk yield by Dairy Gir breeders. According to Durães et al. (2001), the possible causes of low annual genetic trend values in Brazil are because due to flaws in the choice of sires and to use of sires of low accuracy (lower price) to reduce costs. Moreover, Silva et al. (2001) reported that the probable lack of using predicted genetic values for these traits (STA) as a criterion for the selection of sires by breeders may have contributed to the low genetic progress found for these traits.

Considering the two periods independently, although little expressive, most linear traits presented progress in the $2^{\text {nd }}$ period. Some traits presented annual percentage gains practically null $(0.00 \%)$ for males and females in the $1^{\text {st }}$ period, as in the case of rump height, rump angle, body length, rump length, width between ilia, fore udder attachment, thoracic perimeter, leg position - back view, leg position - lateral view; and specifically for females in the $2^{\text {nd }}$ period for teat length, thoracic perimeter, and leg position back view. This also occurred for males in the $1^{\text {st }}$ period for navel length, and in the $2^{\text {nd }}$ period for rump height. Males and females in the $2^{\text {nd }}$ period also presented practically null mean percentage gains for the width between ischia.

The annual genetic changes were more expressive in the subpopulation of females in the $2^{\text {nd }}$ period for temper, udder depth, and rear udder width traits, presenting mean percentage gains of $-0.35 \%, 0.34 \%$, and $0.28 \%$, respectively. The subpopulation of males also showed significant increases in the $2^{\text {nd }}$ period for the temper, navel length, and rear udder width, with annual percentage gains of $-0.66 \%,-0.30 \%$, and $0.29 \%$, respectively. The value found for temper in the subpopulation of males $(-0.66 \%)$ was the highest annual percentage gain found among the linear traits in the whole evaluated period. Absence of genetic improvement can be due to an inverse behavior of values to the desirable ones in different periods. Thus, the traits that stood out were teat length (females in the $1^{\text {st }}$ period); navel length (females in the $1^{\text {st }}$ and $2^{\text {nd }}$ periods); fore udder attachment (females in the $2^{\text {nd }}$ period); teat diameter (females and males in the $2^{\text {nd }}$ period); and hoof wall angle, thoracic perimeter, and leg position - back view (males in the $2^{\text {nd }}$ period).

\section{CONCLUSIONS}

The heritability found for most traits allow a perspective of genetic improvement through of selection and corrective mating for purebred Dairy Gir populations. The inexpressive changes found for most linear traits of conformation and management in the whole evaluated period (1938 to 2012) indicated that the selection of Dairy Gir cows has been directed essentially to increase milk yield. The increased use of STA (Standard Transmitting Ability) available in the summary of the National Dairy Gir Breeding Program can favor the genetic progress of these attributes by using this information for corrective matting. The evaluation of two periods of birth-1938$1996\left(1^{\text {st }}\right)$ and 1997-2012 ( $\left.2^{\text {nd }}\right)$ for females, and 1942-1996 (1 $\left.1^{\text {st }}\right)$ and 1997-2009 $\left(2^{\text {st }}\right)$ for malesshowed that although inexpressive, some linear traits of conformation and management presented progress in the $2^{\text {nd }}$ period, especially for temper and for rear udder width, indicating that the publishing of information of genetic evaluations for these attributes may have contributed to the advances found in the population.

\section{ACKNOWLEDGEMENTS}

The authors thank the Associação Brasileira dos Criadores de Gir Leiteiro (ABCGIL), and Empresa Brasileira de Pesquisa Agropecuária EMBRAPA Gado de Leite for providing the data, and Coordenação de Aperfeiçoamento de Pessoal de Nível Superior - Brasil (CAPES; Finance Code 001), for partially funding this study.

\section{REFERENCES}

ABDALLAH, J.M.; MCDANIEL, B.T. Genetic parameters and trends of milk, fat, days open, and body weight after calving in North Carolina experimental. J. Dairy Sci., v.83, p.1364-1370, 2000.

BIGNARDI, A.B.; GORDO, D.G.M.; ALBUQUERQUE, L.G.; SESANA, J.C. Parâmetros genéticos de escore visual do umbigo em bovinos da raça Nelore. Arq. Bras. Med. Vet. Zootec., v.63, p.941947, 2011. 
BOHLOULI, M.; ALIJANI, S.; RAHIMI, M. Genetic relationships among linear type traits and milk production traits of Holstein dairy cattle. Ann. Anim. Sci., v.15, p.903-917, 2015.

BOLIGON, A.A.; DE VARGAS, L.; SILVEIRA, D.D.; ROSO, V.M. et al. Genetic models for breed quality and navel development scores and its associations with growth traits in beef cattle. Trop. Anim. Health Prod., v.48, p.1679-1684, 2016.

CAMPOS, R.V.; COBUCI J.A.; COSTA, C.N.; BRACCINI NETO, J. Genetic parameters for type traits in Holstein cows in Brazil. Rev. Bras. Zootec., v.41, p.2150-2161, 2012.

CANDA, R.A. Seleção para características de leite e corte em animais da raça Guzerá nos rebanhos de duplo propósito. 2014. 116f. Dissertação (Mestrado em Ciências) - Universidade Federal de Viçosa, Viçosa, MG.

DURÃES, M.C.; FREITAS, A.F.; VALENTE, J.; TEIXEIRA, N.M.; BARRA, R.B. Tendência genética para a produção de leite e de gordura em rebanhos da raça Holandesa no estado de Minas Gerais. Rev. Bras. Zootec., v.30, p.66-70, 2001.

EVERLING, D.M.; RORATO, P.R.N.; ARAUJO, R.O.; BOLIGON, A.A. et al. Associação genética de escores de conformação com características de crescimento em bovinos da raça Angus. Pesqui. Agropecu. Bras., v.47, p.1524-1532, 2012.

GROEN, A.F.; STEINE, T.; COLLEAU, J.; PEDERSEN, J. et al. Economic values in dairy cattle breeding, with special reference to functional traits. Livest. Prod. Sci., v.49, p.1-21, 1997.

KOURY FILHO, W.; JUBILEU, J.S.; ELER, J.P.; FERRAZ, J.B.S. et al. Parâmetros genéticos para escores de umbigo e características de produção em bovinos da raça Nelore. Arq. Bras. Med. Vet. Zootec., v.55, p.594-598, 2003.

KRUSZYŃSKI, W.; PAWLINA, E.; SZEWCZUK, M. Genetic analysis of values, trends and relations between conformation and milk traits in Polish Holstein-Friesian cows. Arch. Tierzucht, v.56, p.536546, 2013.

LAGROTTA, M.R.; EUCLYDES, R.F.; VERNEQUE, R.S.; SANTANA JUNIOR, M.L. et al. Relação entre características morfológicas e produção de leite em vacas da raça Gir. Pesqui. Agropecu. Bras., v.45, p.423-429, 2010.

MCMANUS, C.; SAUERESSING, M.G. Estudo de características lineares de tipo em gado Holandês em confinamento total no distrito federal. Rev. Bras. Zootec., v.27, p.906-915, 1998.

MISSANJO, E.M.; IMBAYARWO, C.; EDWARD, V.; HALIMANI, T.E.; TINYIKO, E. Genetic trends production and somatic cell count for Jersey cattle in Zimbabwe born from 1994 to 2005. Trop. Anim.Health Prod., v.44, p.1921-1925, 2012.
MISZTAL, I.; TSURUTA, S.; STRABEL, T.; AUVRAY, B. et al. BLUPF90 and related programs (BGF90). In: WORLD CONGRESS ON GENETICS APPLIED TO LIVESTOCK PRODUCTION, 7., 2002, Montpellier. Proceedings... Montpellier France: [s.n.], 2002. CD-Rom. (Communication number 2807, 2002).

PANETTO, J.C.C.; VERNEQUE, R.S.; PEIXOTO, M.G.C.D.; BRUNELI, F.A.T. et al. Programa nacional de melhoramento do Gir leiteiro - sumário brasileiro de touros - resultado do teste de progênie $8^{\text {a }}$ prova de pré-seleção de touros - maio 2017. Juiz de Fora: Embrapa Gado de Leite, 2017. 96p.

PEREIRA, J. C. C. Melhoramento genético aplicado à produção animal. 6.ed. Belo Horizonte: FEPMVZ, 2012. 758p.

PEREIRA, M.C.; YOKOO, M.J.; BIGNARDI, A.B.; SEZANA, J.C.; ALBUQUERQUE, L.G. Altura da garupa e sua associação com características reprodutivas e de crescimento na raça Nelore. Pesqui. Agropecu. Bras., v.45, p.613-620, 2010.

SANTANA, M.L.JR.; PEREIRA, R.J.; BIGNARDI, A.B.; VERCESI FILHO, A.E. et al. Detrimental effect of selection for milk yield on genetic tolerance to heat stress in purebred Zebu cattle: genetic parameters and trends. J. Dairy Sci., v.98, p.9035-9043, 2015.

SANTOS, R. Zebu: a pecuária sustentável - edição comemorativa dos 75 anos de registro genealógico e 80 anos da ABCZ. Uberaba: Agropecuária Tropical, 2013. 856p.

SARGOLZAEI, M.; IWAISAKI, H.; COLLEAU, J.J. CFC: a tool for monitoring genetic diversity. In: Proceedings in 8th World Congress on Genetics Applied to Livestock Production, Belo Horizonte (Brazil), 13-18, 2006.

SILVA, M.V.G.B.; FERREIRA, W.J.; COBUCI, J.A.; GUARAGNA, G.P.; OLIVEIRA, P.R.P. Estimativas de tendência genética para características produtivas em um rebanho do ecótipo Mantiqueira. Rev. Bras. Zootec., v.30, p.1466-1475, 2001.

TETZNER, T.A.D. Gir leiteiro: a nossa raça. Ribeirão Preto: Independente, 2016. 292p.

VERNEQUE, R.S.; MARTINEZ, M.L.; TEODORO, R.L. Cow and sire genetic evaluation from Gyr breed based on partial records of milk production. Rev. Bras. Zootec., v.29, p.1060-1066, 2000.

WENCESLAU, A.A.; LOPES, P.S.; TEODORO, R.L.; VERNEQUE, R.S. et al. Estimação de parâmetros genéticos de medidas de conformação, produção de leite e idade ao primeiro parto em vacas da raça Gir leiteiro. Rev. Bras. Zootec., v.29, p.153-158, 2000. 